\title{
RIVIEW SKEMA ACFTA TERHADAP EKSPOR INDONESIA KE TIONGKOK, HONGKONG DAN ASEAN
}

\author{
I Made Adnyana \\ Dosen Sekolah Pascasarjana Magister Sains Manajemen \\ Universitas Nasional Jakarta \\ Madeadnyana99@yahoo.co.id
}

\begin{abstract}
ABSTRAK
Selain adanya Persetujuan Bali II 2003 tentang Masyarakat Ekonomi ASEAN, Indonesia yang menjadi salah satu Negara ASEAN, telah pula membentuk kerjasama perdagangan dengan Tiongkok ACFTA (ASEAN-China Free Trade Agreement) dengan empat skema: Early Harvest Program (EHP), Normal Track (NT) Sensitive Track (ST) and Highly Sensitive Track (HST). Metode studi dengan menggunakan model New Trade Theory, yaitu melibatkan determinan Comparative Advantage, dengan analisis regresi, dan dengan focus data tentang nilai ekspor triwulanan tahun 1996 sampai dengan tahun 2013. Temuan studi ini adalah bahwa komoditas yang mengalami pertumbuhan terbesar ekspor ke semua negara pada tahun 2010 adalah komoditas 15, 87, 29, dan 40. Sementara komoditas 87 dan 27 adalah komoditas ekspor yang pertumbuhannya relatif stabil. Sedangkan komoditas 26 justru mengalami penurunan.
\end{abstract}

Kata kunci: skema ACFTA, ekspor Indonesia, Tiongkok, Hongkong

\section{ABSTRACT}

In addition to the free trade accord of Bali II, Indonesia has also agreed to implement ACFTA with RRChina and Hongkong. Four schemes agreed up on are Early Harvest Program (EHP), Normal Track (NT) Sensitive Track (ST) and Highly Sensitive Track (HST). The method used in the study is applying New Trade Theory model, i.e. involving Comparative Advantage determinants, along with regression analysis. The study focuses on data on export volume of 1996 up to 2013 on three-monhly basis. The finding of the study is that certain commodities have gained promising export in 2010; steady export growth has been 
experienced by two commodities numbered as 87 and 27 at the schemes. The number 26 commodity at the scheme experienced the decline.

Keywords: ACFTA schemes, exsport from Indonesia, RR China, Hongkong

\section{PENDAhUluAN}

\subsection{Latar Belakang}

Indonesia bersama anggota ASEAN lain telah membentuk kerjasama perdagangan dengan Tiongkok ACFTA (ASEAN-China Free Trade Agreement). Hal ini dilatarbelakangi oleh peningkatan perdagangan negaranegara ASEAN dengan Tiongkok. Tiongkok merupakan salah satu mitra dagang utama ASEAN, sementara ASEAN juga merupakan pemasok kebutuhan Tiongkok, khususnya bahan baku. Potensi kerjasama perdagangan yang masih terbuka lebar direalisasikan dalam bentuk penandatanganan kerangka kerjasama tahun 2002.

ACFTA terdiri atas empat skema: Early Harvest Program (EHP), Normal Track (NT) Sensitive Track (ST) and Highly Sensitive Track (HST). Skema pertama (EHP) dimulai dengan mengeliminasi tarif impor yang dimulai dari 2004 menjadi nol persen pada 2006. EHP mencakup produkproduksector pertanian HS kode 01-08 diantaranya binatang hidup, ikan, tumbuhan, sayuran, dll. Skema kedua (NT) dimulai pada Juli 2005 dengan target tarif impor 0 persen pada 2010 (NT I). NT II adalah perpanjangan opsi mundur NT I, ditargetkan pada 2012. Skema ST dibagi menjadi 3 kelompok: SensitiveList (SL), Highly SensitiveList (HSL), dan daftar pengecualian umum (General Exclusion List - GEL). SL mengurangi tariff impor menjadi maksimum 20 persen dari 2012 sampai 2017 dan 0-5 persen pada 2018. Sedangkan HSL ditargetkan pada tahun 2015 dengan maksimum tarif 50 persen. Untuk GEL tidak diliberalisasikan, jadi tariff berlaku tetap tarif Most Favoured Nation (Setiawan, 2012).

Semenjak mulai adanya pengurangan tarif impor pada sektor pertanian tahun 2004, celah antara ekspor Indonesia ke Tiongkok dan impor dari Tiongkok semakin menganga. Berdasarkan data FAO, Indonesia mulai memasuki defisit perdagangan dengan Tiongkok pada beberapa komoditi seperti buah-buahan dan sayur-sayuran. Serbuan produk-produk Tiongkok semakin menekan pasar Indonesia dan ekspor Indonesia ke Tiongkok untuk komoditas tersebut menurun tajam. Volume impor buah dari Tiongkok meningkat hampir sepuluh kali lipat dari 1999 ke 2004 (Tambunan dan Suparyati, 2009). Demikian juga untuk impor sayuran yang meningkat 235 kali dari tahun 1998 ke 2004. Berkebalikan dengan impor, volume ekspor buah menurun 19 kali untuk periode yang sama. Semakin tingginya impor 
Indonesia dari Tiongkok akibat implementasi ACFTA bisa mengancam keberlangsungan pasar domestik karena besarnya skala ekonomi dan melimpahnya tenaga kerja murah di Tiongkok. Komoditas lokal yang berbasis tenaga kerja harus bersaing keras dengan produk Tiongkok.

Selain dampak negatif ACFTA pada ekspor Indonesia, khususnya di sektor pertanian ada beberapa pihak yang menyatakan bahwa secara umum, ACFTA memberikan dampak positif pada perdagangan Indonesia. Marks (2012)meneliti data perdagangan ACFTA dari tahun 2010 dengan menggunakan model komprehensif partial-equilibrium. Hasil studinya adalah bahwa secara keseluruhan Indonesia mengalami neraca perdagangan positif dari ACFTA, meskipun justru mengalami defisit perdagangan dengan Tiongkok. Ibrahim, Permata,dkk, 2010 pada analisis dengan CGE model menyimpulkan bahwa penciptaan perdagangan neto (net trade creation) dari perdagangan internasional Indonesia adalah sebesar 2 persen dan pertumbuhan ekspor meningkat 1,8 persen. Selain Indonesia, peningkatan ekspor negara-negara ASEAN ke Tiongkok juga dialami oleh Malaysia, Singapura, dan Thailand.

Penelitian tentang pengaruh ACFTA terhadap ekspor Indonesia dan Tiongkok telah juga dilakukan oleh Setiawan (2012) dengan menggunakan model ekonometrik ARIMA. Hasil peramalan dengan ARIMA ini digunakan sebagai nilai ekspor simulasi seandainya tidak ada penerapan ACFTA. Dari output model diperoleh pertumbuhan ekspor Indonesia telah meningkat ratarata sebesar 5,8 persen per tahun semenjak pengurangan tarif impor skema ACFTA mulai berlaku. Nilai ini sama dengan meningkatnya pertumbuhan ekspor sebanyak 1,36 kali lipat jika dibandingkan tidak adanya skema ACFTA. Sementara bagi Tiongkok, skema ACFTA meningkatkan pertumbuhan ekspor rata-rata jauh lebih besar dibanding Indonesia, yaitu sebesar 18,6 persen pertahun atau meningkat 7,7 kali lipat.

Sebagian besar komoditas yang diperdagangkan dalam pasar ASEAN dan Tiongkok adalah komoditas berbasis sumber daya alam, seperti CPO dan karet. Manfaat terbesar ACFTA pada Indonesia terlihat pada tekstil dan produk dari tekstil, mesin dan perlengkapan listrik, serta industri lain. Menurut Yue, 2004, ada peningkatan signifikan pada perdagangan intraindustri. Masih terbuka peluang diversifikasi ekspor untuk peningkatan ekspor Indonesia khususnya komoditas berbasis industri.

Semakin banyaknya kerangka kerjasama perdagangan internasional Indonesia dengan negara lain menimbulkan ketertarikan untuk melihat lebih detail pada komoditas unggulan dan pasar ASEAN.

\subsection{Pertanyaan Penelitian}

Apakah ACFTA berpengaruh positif terhadap komoditas ekspor unggulan Indonesia ke negara Tiongkak, Hongkong dan ASEAN? 


\subsection{Tujuan Penelitian}

Untuk mengetahui pengaruh ACFTA terhadap komoditas ekspor unggulan Indonesia ke negara Tiongkok, Hongkong dan ASEAN

\subsection{Hipotesis}

Ekspor Indonesia pada komoditas unggulan mengalami peningkatan setelah berlakunya kerjasama ACFTA.

\section{METODOLOGI}

Negara tujuan ekspor yang dianalisis dalam studi ini adalah negara mitra dagang utama di Tiongkok, Hongkong, dan ASEAN-4 (Malaysia, Philipina, Singapura, Thailand). Data yang digunakan dalam studi ini adalah data nilai ekspor triwulanan tahun 1996 sampai dengan tahun 2013. Pemilihan komoditas utama ekspor Indonesia adalah berdasar total nilai transaksi ekspor Indonesia menurut bab HS ke-enam negara terpillih sebagai berikut:

27: Bahan bakar mineral, minyak mineral dan produk sulingannya; zat mengandung bitumen; malan mineral

85: Mesin dan alat listrik serta bagiannya; pesawatperekam dan pesawat reproduksi suara, pesawattelevisi dan bagian serta perlengkapan dari barangyang semacam itu

15: Minyak dan lemak hewani atau nabati dan produk disosiasinya; lemak olahan yang dapat dimakan; malam hewani atau malam nabati

84: Reaktor nuklir, ketel uap, mesin dan pesawatmekanik; bagiannya

26: Bijih logam, terak dan abu

40: Karet dan barang terbuat dari karet

74: Tembaga dan barang terbuat dari tembaga

29: Bahan Kimia Organik

87: Kendaraan selain yang bergerak di atas rel kereta api atau trem, dan bagian serta perlengkapannya

48: Kertas dan kertas karton; barang dari pulp kertas, dari kertas atau dari kertas karton

Secara rata-rata, total ekspor sepuluh komoditas utama Indonesia ke negara tujuan dalam studi ini berkontribusi sebesar 69,41 persen.Share tertinggi adalah pada bab 27 yaitu sebesar 27,86 persen dan disusul oleh bab 85 sebesar 9,75 persen. Komoditas tersebut masuk dalam skema NT (Normal Track), sehingga penentuan mulai berlakunya skema ACFTA untuk dummy variabeladalah dengan melihat tarif impor menjadi 0 persen, yaitu Januari 2010. Pada skema NT, mulai Januari 2010, tarif impor ditargetkan menjadi 0 persen dengan perpanjangan sampai dengan 2012. 
Untuk melihat pengaruh ACFTA terhadap ekspor Indonesia pada masing-masing komoditas unggulan pada studi ini digunakan model regresi OLS. Sebagai variabel terikat adalah ekspor Indonesia ke negara tujuan pada waktu-t. Sementara itu variabel bebas yang akan digunakan: nilai ekspor periode sebelumnya, total GDP negara asal dan negara tujuan, Similarity Index, Relative Faktor Endowment (RFE), Nilai tukar, terakhir adalah ACFTA sebagai variabel dummy).

Model yang digunakan dibawah adalah berbasis New Trade Theory, yaitu melibatkan determinan Comparative Advantage diantaranya total ukuran ekonomi negara, kemiripan ukuran ekonomi, dan perbedaan pada relative factor endowment. (Baltagi, Egger, et al 2003).

$\mathrm{TGDP}_{\mathrm{Ijt}}=\ln \left(\mathrm{GDP}_{\mathrm{It}}+\mathrm{GDP}_{\mathrm{jt}}\right)$

Relative Factor Endowment $\left(\mathrm{RFE}_{\mathrm{jj}}\right)=\left|\ln \left(\frac{G D F_{I t}}{F_{\mathrm{I}}}\right)-\ln \left(\frac{G D P_{j t}}{F O P_{j t}}\right)\right|$

Similarity index $\left(\mathrm{SI}_{\mathrm{jjt}}\right)=\ln \left[1-\left(\frac{G D P_{l t}}{G D P_{l t}+G D P_{l t}}\right)^{2}-\left(\frac{G D P_{j t}}{G D P_{l t}+G D P_{j t}}\right)^{2}\right]$

TGDP $=$ total PDB Indonesia dan negara tujuan pada waktu-t

RFE = mengukur perbedaan capital endowment pada waktu-t, yang digambarkan dengan perbedaan GDP perkapita Indonesia dan negara tujuan. GDP perkapita disini adalah sebagai pendekatan rasio modal-tenaga kerja. Semakin besar perbedaan capital endowment-nya, maka semakin sedikit volume perdagangan intra-industry.

Menurut teorema Heckscher-Ohlin, faktor endowment yang semakin berbeda antar negara akan lebih memicu perdagangan internasional. Sementara menurut hipotesis Linder, perdagangan justru akan terjadi pada dua negara yang memiliki kebutuhan ekonomi yang sama, dicerminkan dengan perbedaan faktor endowment yang cenderung kecil. Negara dengan ukuran ekonomi (SI) yang mirip dan faktor endowment (RFE) yang mirip dimungkinkan lebih banyak transaksi perdagangan. Hal inilah yang mendasari teorema perdagangan intra-industry.

$\mathrm{SI}=$ mencerminkan kemiripan antara Indonesia dan negara tujuan.

RER = penurunan mata uang domestik suatu negara akan menyebabkan menurunnya harga relatif ekspor sehingga meningkatkan nilai ekspornya. Sebaliknya, harga relatif impor akan menurun sehingga menyebabkan nilai impor menurun. Nilai tukar riil adalah nilai tukar nominal antar negara dibagi dengan rasio indeks harga masing-masing.

$R E R_{l j t}=e_{I j t} \frac{C P I_{j t}}{C P I_{I t}}$

Dimana

$e_{i j t}=$ nilai tukar nominal Indonesia dan Negara tujuan pada waktu-t

$C P I_{j t}=$ IHK Negara tujuan pada waktu-t 
$C P I_{I t}=$ IHK Negara asal pada waktu-t

Model regresi OLS yang digunakan dalam studi ini adalah:

$$
\begin{gathered}
\ln X_{l j t}=\beta_{0}+\beta_{1} X_{l j(t-1)}+\beta_{2} T G D P_{l j t}+\beta_{3} S I_{l j t}+\beta_{4} R F E_{l j t}+\beta_{5} l n R E R_{l j t} \\
+\beta_{5} A C F T A_{l j t}+\varepsilon_{l j t}
\end{gathered}
$$

Dimana

$X_{I j t}=$ ekspor Indonesia ke Negara-j pada waktu-t

$X_{l j(t-1)}=$ ekspor Indonesia ke Negara-j pada waktu-t-1

$T G D P_{I j t}=$ total PDB Indonesia dan Negara-j pada waktu-t

$S I_{l j z}=$ Similarity Index, seperti telah dijelaskan sebelumnya

$R F E_{i j t}=$ Relative Factor Endowment, seperti telah dijelaskan sebelumnya

$R E R_{E j t}=$ Nilai tukar Rupiah dan Negara-j pada waktu-t

ACFTA $_{l j t}=$ Variabel dummy, bernilai 1 jika Indonesia dan Negara-j pada waktu-t berada pada skema ACFTA, yaitu triwulan I/ 2010 sebagai benchmark tariff impor 0 persen untuk NT

\section{PEMBAHASAN}

\subsection{Hubungan Perdagangan Indonesia-Tiongkok}

Impor mendominasi perdagangan Indonesia-Tiongkok semenjak tahun 1996. Dari tahun 1996-2007, Indonesia mengalami surplus perdagangan dengan Tiongkok, tapi terjadi perubahan dari tahun 2008 sampai dengan 2013. Adapun komoditas impor dari Tiongkokyang mengalami peningkatan adalah 74, 85, 84, 15. Pada tahun 2008 terjadi lonjakan impor yang disebabkan oleh penambahan cakupan kawasan berikat. Pada tahun 2009, ekspor impor Indonesia ke Tiongkok mengalami penurunan sebesar minus 1 dan minus 8 persen. Sedangkan ekspor dan impor ke dan dari Tiongkok pada tahun 2010 kembali tumbuh positif. Hal ini bisa disebabkan karena perekonomian sudah mulai pulih dari goncangan krisis ekonomi global 2009. Selain itu, tumbuhnya perdagangan IndonesiaTiongkok bisa terjadi karena pengurangan tarif impor pada skema ACFTA.

Pengurangan tarif impor ACFTA dianggap menguntungkan untuk beberapa perusahaan, karena bahan baku industri dari impor akan lebih mudah diperoleh, dengan harga yang sangat murah.Ekspor ke Tiongkokpada tahun 2010 mengalami penurunan pada komoditas 84 . Komoditas terpilih memiliki kontribusi sekitar 72 persen dari total ekspor ke Tiongkok.Dari tahun 1996-2013, share tertinggi 10 komoditas terpilih terhadap total adalah pada tahun 2011, yaitu sebesar 85 persen. Komoditas 27 adalah komoditas ekspor utama, disusul komoditas 15 . 


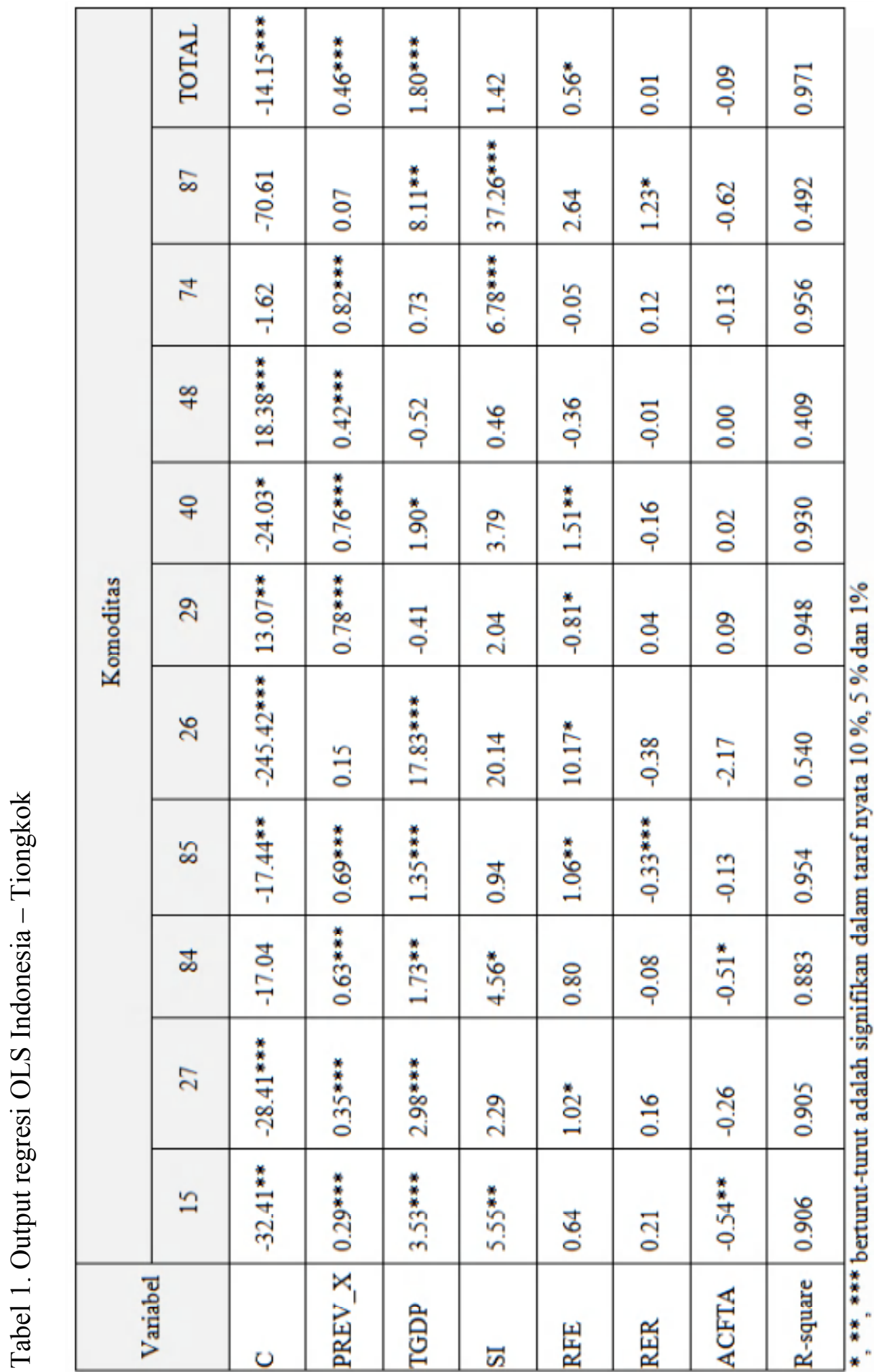


Pada ekspor Indonesia ke Tiongkok tahun 1996-2013, model regresi OLS rata-rata mampu menjelaskan variasi ekspor dengan baik, yaitu diatas 88 persen. Namun untuk komoditas 48 dan 87, model OLS hanya menjelaskan variasi model dibawah 50 persen.

Ekspor sebagai suatu proses yang berkelanjutan dapat terlihat pada variabel ekspor di triwulan sebelumnya, dimana semua koefisien variabel signifikan pada 1 persen dan bernilai positif, kecuali pada komoditas 26 dan 87. Diantara semua komoditas utama, total PDB berperan paling besar terhadap ekspor komoditas 15.

Ekspor Indonesia ke Tiongkok untuk komoditas 27, 85, 26, 40, dan total lebih didasari atas perbedaan factor endowment, sehingga tidak sesuai dengan intra industry trade. Akan tetapi, hanya ekspor komoditas 29 ke Tiongkok yang didasari atas kemiripan factor endowment dan sesuai dengan intra industry trade.

RER signifikan dan bernilai negatif hanya pada komoditas 85 . Tidak seperti teori ekonomi, pada hasil output regresi menyatakan bahwa tiap persen depresiasi Rupiah justru menurunkan nilai ekspor sebesar 0,33 persen. Sementara pada komoditas 87 , RER justru bernilai positif yang berarti setiap perpsen depresiasi Rupiah akan mendorong nilai ekspor komoditas 87 sebesar 1,24 persen. Pada komoditas lain, depresiasi tidak mempengaruhi nilai ekspor ke Tiongkok.

Berlakunya skema kerjasama perdagangan ACFTA ternyata tidak sesuai dengan harapan, bahwa ternyata ACFTA memberikan dampak negatif pada ekspor Indonesia ke Tiongkok, khususnya pada komoditas 15 dan 84 . ACFTA tidak mampu meningkatkan ekspor Indonesia pada komoditas utama, tetapi justru melemahkan nilai ekspor pada komoditas tersebut. Ekspor pada komoditas lain tidak terpengaruh ACFTA.

\subsection{Hubungan Perdagangan Indonesia-HK}

Kerjasama perdagangan Indonesia-HK dari tahun 1996-2013 didominasi oleh ekspor. Komoditas ekspor utama adalah komoditas 27. Pada tahun 2008, impor dari Hongkong melonjak 435 persen dari tahun sebelumnya, yang didorong oleh 6 komoditas terpilih yang pertumbuhannya lebih dari 230 persen. Ini disebabkan penambahan cakupan kawasan berikat. Meskipun Indonesia masih mengalami surplus perdagangan dengan $\mathrm{HK}$, namun nilainya semakin mengecil. 


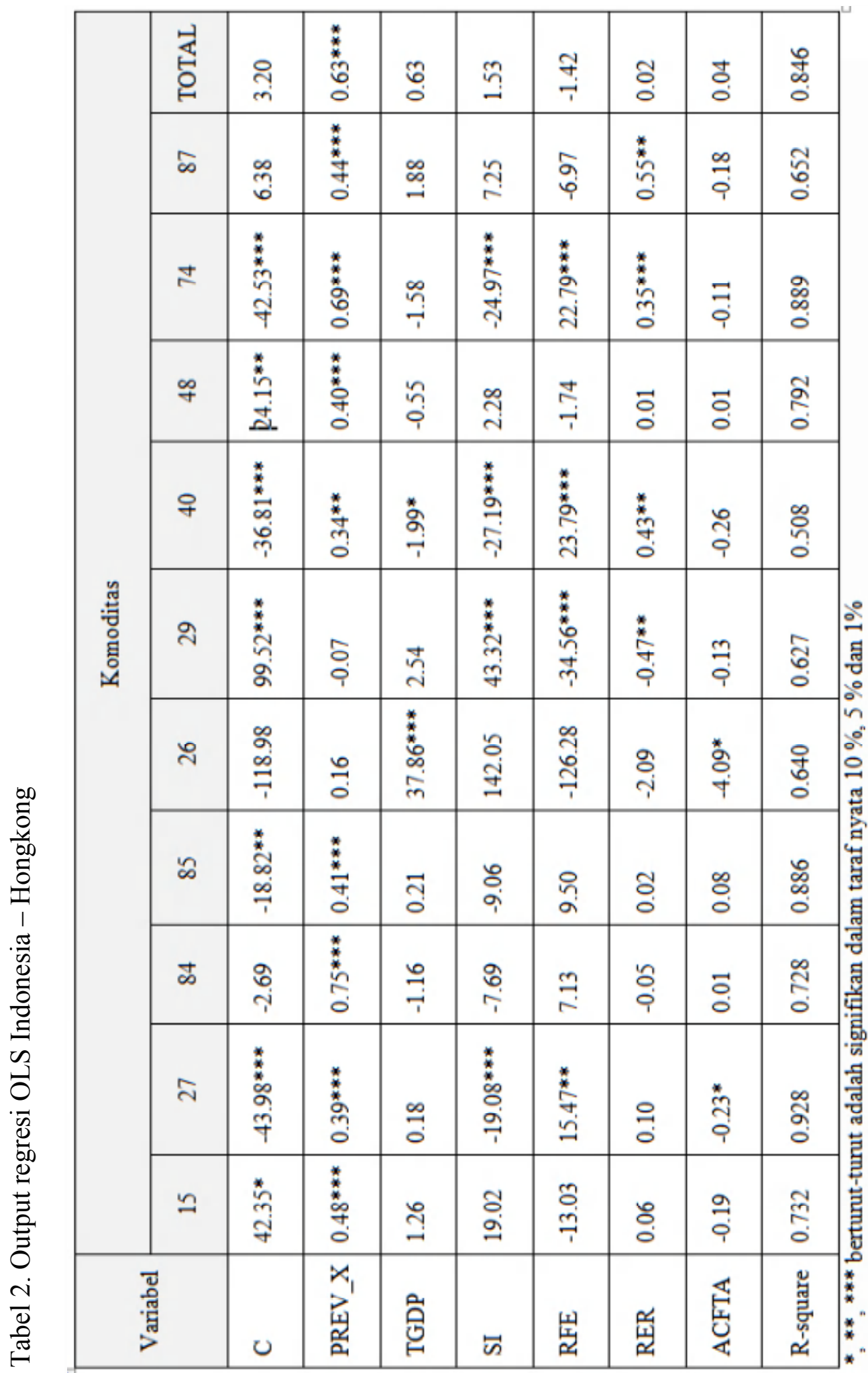


Ekspor pada periode sebelumnya mempunyai peran penting pada ekspor periode sekarang, tercermin pada hampir semua komoditas utama yang signifikan dan bernilai positif, kecuali komoditas 26 dan 29.

Variabel SI dan RFE pada model signifikan pada ekspor komoditas 27, 29, 40, dan 74. Ekspor Indonesia ke Hongkong untuk komoditas tersebut (kecuali 29) tidak sesuai dengan intra industry trade. Seperti halnya ekspor Indonesia ke Tiongkok, pada komoditas 29 ekspor lebih didasarkan atas teori perdagangan internasional klasik, yaitu keunggulan komparatif (comparative advantage).

Skema perdagangan ACFTA memberikan dampak negatif ekspor Indonesia ke Hongkong komoditas pada 27 dan 26, berbeda dengan komoditas ekspor Indonesia ke Tiongkok yang terdampak negatif. Akan tetapi, ACFTA tidak memberikan pengaruh apapun pada komoditas lain.

\subsection{Hubungan Perdagangan Indonesia-ASEAN-4}

\section{Malaysia}

Perdagangan Indonesia dengan Malaysia selalu didominasi ekspor. Meskipun pada tahun 2008, Indonesia mengalami defisit perdagangan dengan Malaysia. Yang menjadi komoditas ekspor utama adalah komoditas 27. Komoditas ini mulai menduduki peringkat utama pada tahun 2000. Komoditas ini juga menjadi komoditas impor utama dari Malaysia. Ekspor Indonesia ke Malaysia lebih berdasar atas keunggulan komparatif yang dilatarbelakangi perbedaan factor endowment pada komoditas 84, 85, 29, 48, dan 87 .

\section{Filipina}

Perdagangan Indonesia- Filipina didominasi oleh ekspor dari tahun ke tahun. Sampai dengan tahun 2013, komoditas 27 adalah menjadi komoditas ekspor andalan Indonesia ke Filipina, yang berkontribusi sebesar lebih dari 20 persen. Ekspor ke Filipina didasarkan atas perbedaan factor endowment, yaitu pada komoditas 15, 74, dan 87 . 


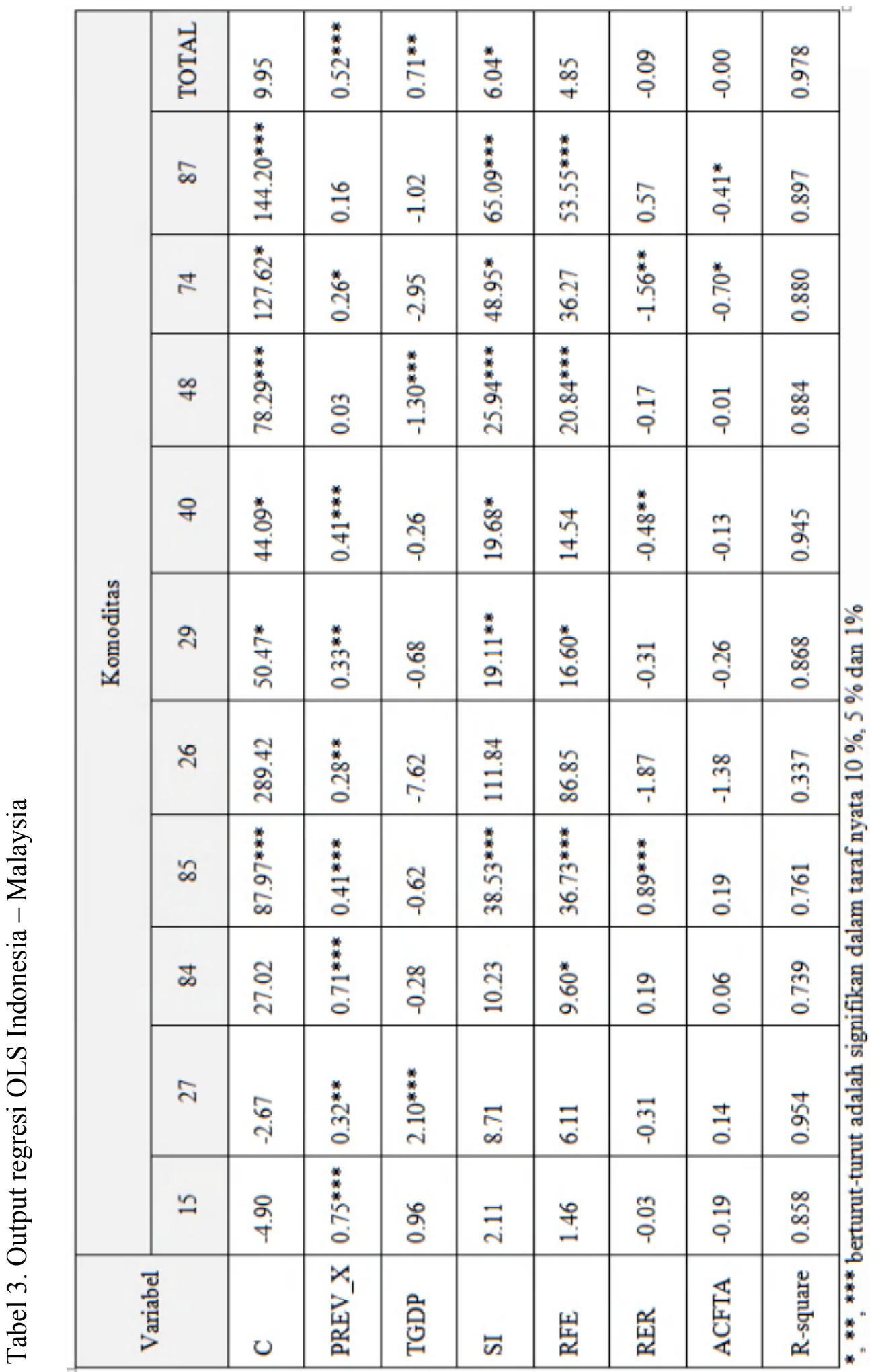




\begin{tabular}{|c|c|c|c|c|c|c|c|c|c|}
\hline * & 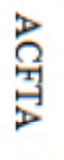 & 预 & $\begin{array}{l}\text { 车 } \\
\text { 闯 }\end{array}$ & $\tilde{n}$ & 凷 & 覮 & $\Omega$ & & \\
\hline$\stackrel{0}{\infty}$ & b & i & 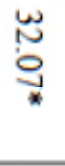 & $\begin{array}{l}\text { \%ू } \\
\text { के }\end{array}$ & 웅 & $\underset{*}{\circ}$ & 岕 & $\vec{u}$ & \multirow{11}{*}{ 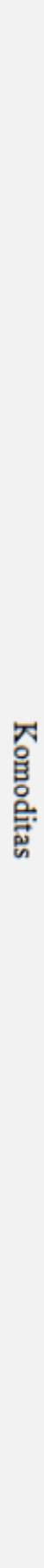 } \\
\hline $\begin{array}{l}\circ \\
\infty \\
\stackrel{\infty}{W}\end{array}$ & $\stackrel{\circ}{\circ}$ & b & $\begin{array}{l}\dot{1} \\
\text { gे }\end{array}$ & $\begin{array}{l}\dot{b} \\
\dot{0}\end{array}$ & $\begin{array}{l}w \\
\underset{t}{*} \\
* \\
*\end{array}$ & $\underset{*}{\stackrel{0}{*}}$ & $\underset{\substack{ \pm * \\
*}}{\stackrel{b}{ \pm}}$ & N & \\
\hline$\stackrel{\circ}{\stackrel{0}{\Xi}}$ & 영 & $\underset{\substack{\infty \\
* \\
*}}{\dot{w}}$ & $\begin{array}{l}\vec{\omega} \\
\text { s }\end{array}$ & $\begin{array}{l}\overrightarrow{4} \\
\dot{8}\end{array}$ & $\underbrace{i}_{0}$ & $\begin{array}{l}\underset{\infty}{\infty} \\
* \\
*\end{array}$ & 卢 & $\stackrel{\infty}{+}$ & \\
\hline 옹 & ' & $\begin{array}{l}b \\
8\end{array}$ & 苛 & 官 & 응 & $\begin{array}{l}0 \\
\infty \\
+ \\
* \\
* \\
*\end{array}$ & 옵 & $\stackrel{\infty}{\sim}$ & \\
\hline : & $\underset{*}{\stackrel{b}{w}}$ & $\stackrel{0}{=}$ & 岕 & $\begin{array}{l}\dot{\alpha} \\
\text { ă }\end{array}$ & ô & 용 & के & ๙ & \\
\hline $\mid \begin{array}{l}\infty \\
\stackrel{\infty}{\infty} \\
\end{array}$ & $\underset{ \pm}{\stackrel{O}{+}}$ & i & 岕 & $\stackrel{\stackrel{N}{\ominus}}{ }$ & $\stackrel{\circ}{\dot{v}}$ & \begin{tabular}{l}
$\stackrel{0}{W}$ \\
\multirow{*}{*}{} \\
$*$
\end{tabular} & 灾 & $\tilde{b}$ & \\
\hline $\begin{array}{l}0 \\
\infty \\
\stackrel{+}{W}\end{array}$ & $\stackrel{\circ}{\ominus}$ & 엄 & $\underset{+}{\stackrel{ \pm}{ \pm}}$ & $\vec{a}$ & 붕 & 응 & $\begin{array}{l}\infty \\
\dot{b}\end{array}$ & 古 & \\
\hline $\begin{array}{l}0 \\
\infty \\
N\end{array}$ & 웅 & 영 & $\stackrel{\infty}{\infty}$ & $\stackrel{\circlearrowright}{\ominus}$ & 웅 & 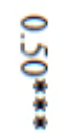 & 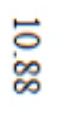 & 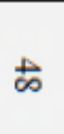 & \\
\hline $\begin{array}{l}0 \\
\text { ज్ }\end{array}$ & i் & 음 & $\begin{array}{l}\infty \\
+\infty \\
8 \\
0 \\
* \\
*\end{array}$ & 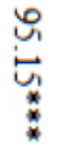 & $\dot{\omega}_{*}^{\prime}$ & 옻 & 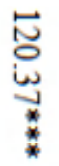 & $\vec{I}$ & \\
\hline $\begin{array}{l}0 \\
\text { 迸 } \\
\text { N }\end{array}$ & 웅 & 웅 & \begin{tabular}{l}
$\vec{\infty}$ \\
$\dot{u}$ \\
\multirow{*}{*}{}
\end{tabular} & $\underset{*}{\stackrel{N}{*}}$ & $\stackrel{0}{\overrightarrow{0}}$ & $\begin{array}{l}\circ \\
\text { gे } \\
* \\
*\end{array}$ & $\stackrel{N}{N}$ & $\stackrel{\infty}{-\infty}$ & \\
\hline 응 & 웅 & 웅 & $\underset{\infty}{\stackrel{\infty}{+}}$ & ur & $\begin{array}{l}\vec{\infty} \\
* \\
* \\
*\end{array}$ & $\stackrel{0}{\stackrel{0}{*}}$ & 方 & $\begin{array}{l}\text { 법 } \\
\text { 苞 }\end{array}$ & \\
\hline
\end{tabular}




\section{Singapura}

Dari tahun 1996-2004, komoditas utama ekspor ke Singapura adalah komoditas 85, 84 dan 27. Share komoditas 27 dari tahun ke tahun semakin besar, mencapai 38 persen pada tahun 2013. Sementara dari tahun 2005-2013, Indonesia mengalami defisit perdagangan dengan Singapura. Bahkan impor komoditas 27 mencapai 60 persen.

\section{Thailand}

Secara umum, Indonesia mengalami defisit perdagangan dengan Thailand. Pernah terjadi surplus perdagangan dengan Thailand, yaitu pada tahun 1998, 2001, dan 2002. Namun demikian, surplus perdagangan pada periode tersebut maksimal 11 persen. Komoditas utama ekspor Indonesia ke Thailand adalah komoditas 27.Ekspor komoditas ini ke Thailand lebih berdasar atas keunggulan komparatif. Demikian juga ekspor pada komoditas $84,74,87$, dan total. 


\begin{tabular}{|c|c|c|c|c|c|c|c|c|c|}
\hline * & 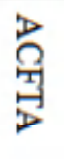 & $\begin{array}{l}\text { 㼛 } \\
\text { 另 }\end{array}$ & 空 & 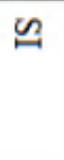 & 占 & 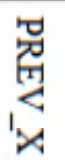 & $\Omega$ & & \\
\hline 잉 & ن & $\begin{array}{l}0 \\
8 \\
8 \\
* \\
*\end{array}$ & $\ddot{\infty}$ & $\begin{array}{l}\dot{\omega} \\
+\end{array}$ & \begin{tabular}{l}
$N$ \\
$\infty$ \\
\multirow{*}{*}{} \\
$*$
\end{tabular} & $\underset{+}{\stackrel{0}{+}}$ & $\begin{array}{l}\text { b } \\
\text { O } \\
\text { \& } \\
*\end{array}$ & $\vec{u}$ & \multirow{11}{*}{ 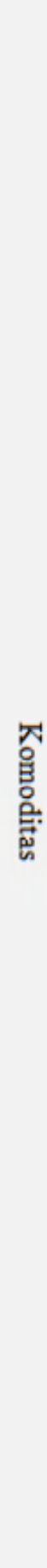 } \\
\hline$\underset{\omega}{\stackrel{0}{\sigma}}$ & 说 & 잉 & 'ب & $\begin{array}{l}u \\
\infty \\
+\infty \\
* \\
*\end{array}$ & 옹 & $\begin{array}{l}\underset{\omega}{\omega} \\
* \\
*\end{array}$ & $\underbrace{N}_{*}$ & N & \\
\hline ○ & $\begin{array}{l}0 \\
\dot{\infty}\end{array}$ & $\stackrel{\dot{0}}{\mathfrak{E}_{*}^{*}}$ & 芯 & 官 & 응 & $\begin{array}{l}0 \\
0 \\
0 \\
* \\
*\end{array}$ & $\stackrel{\circ}{\stackrel{\circ}{\infty}}$ & $\stackrel{\infty}{+}$ & \\
\hline $\begin{array}{l}\text { o } \\
\text { 吕 } \\
\text { w }\end{array}$ & 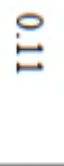 & \begin{tabular}{l}
$\dot{0}$ \\
$\dot{\omega}$ \\
\multirow{*}{*}{} \\
$*$
\end{tabular} & $\begin{array}{l}w \\
\dot{\omega} \\
\infty \\
* \\
*\end{array}$ & $\underbrace{\dot{\omega}}$ & $\stackrel{\circ}{\stackrel{ }{\perp}}$ & \begin{tabular}{l}
0 \\
$\dot{L}$ \\
\multirow{2}{*}{} \\
$*$
\end{tabular} & $\underbrace{\dot{\omega}}_{\dot{\omega}}$ & $\stackrel{\infty}{\circlearrowleft}$ & \\
\hline 怘 & \begin{tabular}{l}
$\dot{a}$ \\
\multirow{2}{*}{} \\
$*$ \\
$*$
\end{tabular} & $\begin{array}{l}\dot{\omega} \\
\stackrel{*}{*} \\
*\end{array}$ & $\underset{\sim}{N}$ & $\begin{array}{l}\text { g } \\
\stackrel{2}{0} \\
*\end{array}$ & $\begin{array}{l}\text { O } \\
\text { 芒 } \\
* \\
*\end{array}$ & 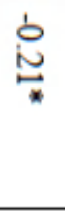 & 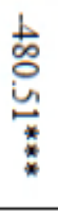 & $\approx$ & \\
\hline 옹 & 웅 & $\stackrel{\dot{0}}{a}$ & $\tilde{N}$ & b & $\begin{array}{l}\dot{0} \\
\text { a }\end{array}$ & 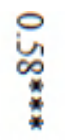 & $\underset{\infty}{\infty}$ & $\tilde{0}$ & \\
\hline 首 & $\stackrel{\dot{0}}{\vec{v}}$ & 응 & \begin{tabular}{l}
$\omega$ \\
\multirow{v}{*}{} \\
$*$
\end{tabular} & $\stackrel{\dot{N}}{\stackrel{\infty}{*}}$ & ì & $\underset{*}{\stackrel{0}{*}}$ & $\stackrel{\dot{D}}{\sim}$ & t & \\
\hline 寍 & $\stackrel{\dot{0}}{\circ}$ & $\begin{array}{l}b \\
\dot{w} \\
0 \\
* \\
*\end{array}$ & $\underset{\substack{\infty \\
+}}{\dot{⿱ 亠}}$ & $\underset{*}{\stackrel{*}{*}}$ & $\begin{array}{l}\stackrel{1}{\bullet} \\
\infty \\
* \\
* \\
*\end{array}$ & $\begin{array}{l}\dot{0} \\
\text { ○ }\end{array}$ & \begin{tabular}{l} 
N \\
\multirow{2}{*}{} \\
$*$ \\
$*$
\end{tabular} & 占 & \\
\hline$\stackrel{\circ}{\stackrel{\infty}{O}}$ & $\begin{array}{l}\dot{b} \\
\text { a }\end{array}$ & $\begin{array}{l}\dot{0} \\
\dot{0} \\
0 \\
*\end{array}$ & $\begin{array}{l}a \\
\stackrel{\infty}{\infty} \\
*\end{array}$ & & $\underset{*}{\stackrel{\oplus}{*}}$ & $\begin{array}{l}0 \\
\text { U } \\
* \\
*\end{array}$ & $\begin{array}{l}\dot{\omega} \\
\text { ه్ } \\
\text { ş }\end{array}$ & $\not \vec{F}$ & \\
\hline$\stackrel{\circ}{\stackrel{\infty}{\Theta}}$ & $\stackrel{\circ}{\omega}$ & $\stackrel{\circ}{\circ}$ & $\underset{\infty}{\stackrel{\infty}{\infty}}$ & 군 & 용 & \begin{tabular}{l} 
O \\
\multirow{*}{*}{} \\
$*$ \\
$*$
\end{tabular} & $\stackrel{\infty}{\infty}$ & $\stackrel{\sim}{\infty}$ & \\
\hline 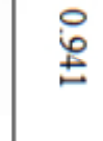 & '요 & ' & b & 岕 & $\begin{array}{l}0 \\
\text { 草 } \\
*\end{array}$ & $\begin{array}{l}\stackrel{0}{ \pm} \\
\stackrel{*}{*} \\
*\end{array}$ & $\begin{array}{l}\text { 응 } \\
\text { \% }\end{array}$ & 官 & \\
\hline
\end{tabular}




\begin{tabular}{|c|c|c|c|c|c|c|c|c|c|}
\hline \multirow{11}{*}{ 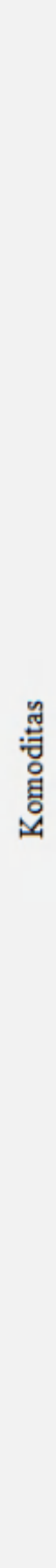 } & 茺 & กั & $\stackrel{*}{\stackrel{*}{ }}$ & $\begin{array}{l}* \\
0 \\
0 \\
\infty \\
\text { i }\end{array}$ & $\begin{array}{l}* \\
\stackrel{*}{*} \\
\stackrel{-}{ \pm}\end{array}$ & 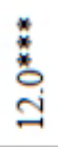 & 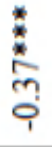 & ปี & ్ํ \\
\hline & $\tilde{\infty}$ & 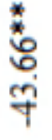 & $\begin{array}{l}* \\
* \\
\text { 웅 } \\
\text { 巳 }\end{array}$ & 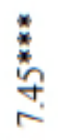 & \begin{tabular}{l} 
* \\
$\stackrel{*}{*}$ \\
\multirow{\sigma}{*}{}
\end{tabular} & \begin{tabular}{l}
$\stackrel{*}{*}$ \\
$\stackrel{*}{*}$ \\
\multirow{n}{*}{}
\end{tabular} & $\stackrel{*}{*} \stackrel{*}{\stackrel{*}{7}}$ & $\begin{array}{l}\text { के } \\
\stackrel{\sim}{\circ}\end{array}$ & ఖั \\
\hline & $\stackrel{ \pm}{ \pm}$ & $\frac{\circ}{\text { คั }}$ & $\begin{array}{l}\stackrel{*}{*} \\
\stackrel{*}{*} \\
\stackrel{0}{\circ}\end{array}$ & $\stackrel{*}{\stackrel{*}{二}}$ & 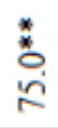 & $\frac{*}{*}$ & \begin{tabular}{l}
$\hat{*}$ \\
\multirow{2}{*}{} \\
\multirow{1}{*}{}
\end{tabular} & 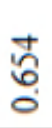 & $\begin{array}{l}\vec{n} \\
\infty \\
0 \\
0\end{array}$ \\
\hline & 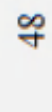 & 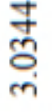 & $\begin{array}{l}\text { ** } \\
\stackrel{*}{\circ} \\
\stackrel{n}{0} \\
0\end{array}$ & ஃ̊ & $\stackrel{m}{=}$ & $\underset{\infty}{ \pm}$ & 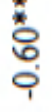 & $\begin{array}{l}\infty \\
\stackrel{\infty}{\circ} \\
\circ\end{array}$ & ふุ \\
\hline & 우 & $\begin{array}{l}\text { aे } \\
\text { à } \\
\text { ㄱ. }\end{array}$ & $\stackrel{\stackrel{\tilde{*}}{*}}{\stackrel{\mathrm{f}}{\circ}}$ & $\stackrel{\mathrm{O}}{\mathrm{i}}$ & ำ & б후 & $\begin{array}{l}\frac{*}{*} \\
\stackrel{*}{*} \\
\text { r }\end{array}$ & $\frac{n}{n}$ & $\underset{ }{\stackrel{\circ}{ }}$ \\
\hline & নે & Ð & ڤั & ర్ & $\stackrel{\infty}{\circ}$ & ले & $\begin{array}{l}\text { *ैo } \\
\text { ஸे } \\
\text { ? }\end{array}$ & $\frac{\sqrt{0}}{0}$ & $\begin{array}{l}\frac{8}{6} \\
0 \\
0\end{array}$ \\
\hline & 기 & $\stackrel{-}{\stackrel{8}{0}}$ & $\underset{⿱ 乛}{ \pm}$ & $\stackrel{n}{\tilde{n}}$ & ర્ల & बं & $\frac{q}{i}$ & 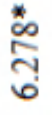 & 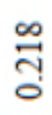 \\
\hline & $\check{\infty}$ & $\frac{9}{m}$ & 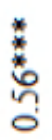 & $\begin{array}{l}\text { గ్ర } \\
0\end{array}$ & 志 & $\begin{array}{l}\text { ডั } \\
\text { ஸे }\end{array}$ & $\frac{v^{*}}{\stackrel{n}{*}}$ & సิ & ষ্ণ \\
\hline & ఉ & \begin{tabular}{l}
$*$ \\
$\stackrel{*}{*}$ \\
$\stackrel{*}{*}$ \\
\multirow{1}{*}{}
\end{tabular} & $\begin{array}{l}\frac{*}{*} \\
\stackrel{*}{*} \\
0\end{array}$ & \begin{tabular}{l}
$*$ \\
\multirow{2}{*}{} \\
$\stackrel{2}{+}$
\end{tabular} & 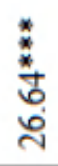 & $\begin{array}{l}* \\
\text { ลี } \\
\text { ปี }\end{array}$ & $\frac{*}{*}$ & 킁 & જે \\
\hline & $\bar{\sim}$ & 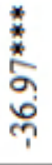 & $\stackrel{2}{\circ}$ & $\stackrel{*}{\stackrel{*}{*}}$ & $\begin{array}{l}\text { * } \\
\text { ปั่ }\end{array}$ & $\begin{array}{l}\text { * } \\
\text { హे }\end{array}$ & 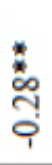 & 웅 & Һ̂ \\
\hline & $\cong$ & 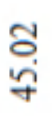 & 웅 & $\begin{array}{l}0 \\
\text { ధ̊ }\end{array}$ & $\begin{array}{l}\infty \\
\infty \\
\text { † }\end{array}$ & $\begin{array}{l}\text { 于े } \\
\text { to }\end{array}$ & ָे & ণ্ & $\stackrel{\circ}{\circ}$ \\
\hline & & ט & 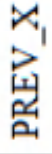 & 号 & 吼 & 岀 & 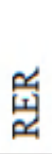 & 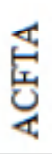 & 㫕 \\
\hline
\end{tabular}


Secara total, ekspor Indonesia ke negara Malaysia, Philipina, Singapura, dan Thailand bersifat dinamis, dan memiliki hubungan erat dengan ekspor periode sebelumnya. Total GDP Indonesia dan semua Negara ASEAN-4 sangat berpengaruh terhadap ekspor Indonesia jika dilihat pada total komoditas.

Ekspor komoditas ke Thailand untuk komoditas 26 tidak terpengaruh depresiasi. Sedangkan depresiasi justru melemahkan nilai ekspor komoditas utama lainnya. Teori ekonomi yang menyatakan bahwa depresiasi akan meningkatkan nilai ekspor tidak terbukti pada ekspor ke Thailand.Demikian juga ekspor Indonesia ke Singapura, untuk ekspor komoditas 15, 84, 85, 26, 48, 74, dan 87 justru semakin melemah dengan terdepresiasinya Rupiah. Skema ACFTA memberikan dampak positif pada ekspor Indonesia ke Thailand untuk komoditas 26 dan total. Namun, kontribusi komoditas 26 terhadap ekspor Indonesia ke Thailand sangat kecil, demikian juga variasi ekspor pada model OLS komoditas 26 sangat kecil. Dengan berlakunya ACFTA, ekspor ke Filipina dan Singapura untuk komoditas 26 terdampak negatif. Sedangkan komoditas yang terdampak negatif dengan adanya ACFTA pada ekspor ke Malaysia adalah komoditas 74. Selebihnya, ACFTA tidak memberikan pengaruh apapun terhadap ekspor Indonesia ke negara ASEAN-4.

Secara umum, ACFTA memberikan dampak negatif terhadap ekspor Indonesia pada komoditas tertentu di negara tujuan yang terkena sampel, kecuali Thailand.

\section{BATASAN PENELITIAN}

Studi ini hanya membahas tentang ekspor, maka hanya dampak positif yang muncul dari skema kerjasama ACFTA di Indonesia. Sementara dampak negatif impor ditelusuri dari tahun 2008 karena penambahan cakupan kawasan berikat.

\section{SIMPULAN}

1. Komoditas yang mengalami pertumbuhan terbesar ekspor ke semua negara pada tahun 2010 adalah komoditas 15, 87, 29, dan 40. Sementara komoditas 87 dan 27 adalah komoditas ekspor yang pertumbuhannya relatif stabil. Sedangkan komoditas 26 justru mengalami penurunan

2. Potensi kerjasama perdagangan Indonesia dengan ASEAN-4 masih terbuka lebar. Ini ditandai dengan meningkatnya ekspor Indonesia ke ASEAN-4 pada 2010. Seperti halnya ekspor, tahun 2010 impor juga mengalami pemulihan. Meskipun ekspor Indonesia ke ASEAN-4 sempat mengalami penurunan pada 2009 akibat krisis ekonomi 
global, namun setelah kerangka ACFTA dengan tarif impor 0 persen mulai berlaku, ekspor kembali membaik. Kelesuan akibat krisis ekonomi global tidak hanya terjadi pada ekspor, namun impor juga mengalami kontraksi sebesar minus 30 persen. Diantara negara ASEAN lain, Indonesia, bersama dengan India dan Tiongkok, adalah negara yang mampu bertahan ketika krisis ekonomi global dan masih mengalami pertumbuhan ekonomi positif. Akan tetapi, karena negara ASEAN lain mengalami goncangan yang cukup parah, maka arus perdagangan internasional Indonesia ke negara ASEAN juga ikut terpengaruh. Meskipun krisis ekonomi global tidak separah krisis ekonomi Asia di tahun 1998, namun krisis ekonomi global lebih membutuhkan waktu pemulihan yang cukup lama.

\section{Saran}

1. Dalam rangka menyambut AEC 2015 (ASEAN Economic Community) sebagai langkah yang lebih komprehensif dari AFTA (Asean Free Trade Area), salah satunya adalah menjadikan ASEAN sebagai sebuah pasar tunggal dan basis produksi. Diharapkan Indonesia tidak hanya menjadi target pasar yang menggiurkan bagi negara importir, tapi juga mampu bersaing sengan negara ASEAN lain. Hal ini dikarenakan populasi penduduk Indonesia adalah 40 persen dari total penduduk ASEAN.

2. Indonesia masih memiliki peluang untuk meningkatkan nilai tambah ekspor. Kemampuan dalam pemanfaatan teknologi, networking, penetrasi pasar, kemampuan negosiasi perdagangan, dan pembenahan infrastruktur mutlak ditingkatkan oleh pelaku bisnis maupun pembuat kebijakan. 


\section{DAFTAR PUSTAKA}

Baltagi, Badi H., Peter Egger, and Michael Pfaffermayr. "A generalized design for bilateral trade flow models." Economics Letters 80.3 (2003): 391-397.

Ibrahim, Meily Ika Permata, Wahyu Ari Wibowo. (2010). "Dampak ACFTA terhadap Perdagangan International Indonesia." Bank of Indonesia.

Marks, S. P. (2012). "Impact on Indonesia of the ASEAN-China Free Trade Agreement." USAID.

Setiawan, Sigit (2012). “Asean-China FTA: Dampaknya terhadap Ekspor Indonesia and Tiongkok." Kementrian Keuangan-RI.

Tambunan, T. and A. Suparyati (2009). "ASEAN-China Trade Liberalisation Effect on Indonesian Agricultural Production and Trade.

Yue, C. S. (2004). Asean-China Free Trade Area. AEP Conference, 1213April. Hongkong, China. 